\title{
DETERMINATION OF BIOLOGICAL AND SENSORY PROFILES OF BISCUITS ENRICHED WITH TEA (CAMELLIA SINENSIS L.) POWDER
}

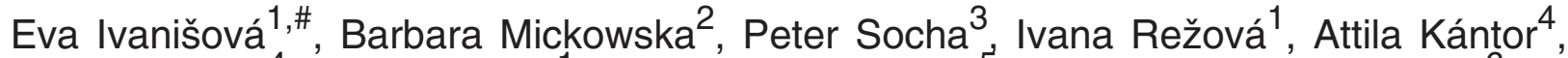 \\ Ladislav Haris ${ }^{4}$, Marián Tokár ${ }^{1}$, Margarita Terentjeva ${ }^{5}$, and Miroslava Kačániová ${ }^{6}$ \\ ${ }^{1}$ Department of Plant Storage and Processing, Faculty of Biotechnology and Food Sciences, Slovak University of Agriculture, \\ Tr. A. Hlinku 2, Nitra SK-94976, SLOVAKIA \\ ${ }^{2}$ Malopolska Centre of Food Monitoring, Faculty of Food Technology, Agriculture University in Cracow, Balicka 122, PL- 30149, POLAND \\ ${ }^{3}$ Research Centre AgroBioTech, Faculty of Biotechnology and Food Sciences, Slovak University of Agriculture, \\ Tr. A. Hlinku 2, Nitra SK-94976, SLOVAKIA \\ ${ }^{4}$ Vitaflóra - Mill Company, Železničný rad 1, Kolárovo SK-94603, SLOVAKIA \\ ${ }^{5}$ Faculty of Veterinary Medicine, Latvia University of Life Sciences and Technologies, 8 K. Helmaña Str., LV-3004, Jelgava, LATVIA. \\ ${ }^{6}$ Department of Microbiology, Faculty of Biotechnology and Food Sciences, Slovak University of Agriculture, \\ Tr. A. Hlinku 2, Nitra SK-94976, SLOVAKIA \\ \# Corresponding author, eva.ivanisova@uniag.sk
}

Communicated by Aivars Bērziṇ̌̌

\begin{abstract}
The aim of this work was to characterise the biological and sensory profile of biscuits enriched with green (1 and 3\%) and black tea (1 and 3\%) powders. Biscuits without the addition of tea were used as a control. Phenolic concentration, flavonoid concentration, and antioxidant activity were determined spectrophotometrically. Amino acid composition was determined using automatic amino acid analyser AAA 400 and crude fibre content using an Ancom analyser. Sensory profiles were evaluated by comparison of enriched and control biscuit samples. The enriched biscuits showed higher phenolic and flavonoid concentration and antioxidant activity estimated by DPPH and phospholybdenum method in comparison with levels in the control group. The best results for antioxidant activity estimated by DPPH and phosphomolybdenum methods were achieved in bis-

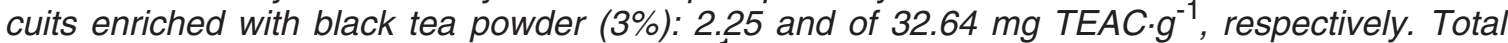
phenolic concentration was $1.16 \mathrm{mg} \mathrm{GAE} \cdot \mathrm{g}^{-1}$, and total flavonoid concentration was $0.13 \mathrm{mg}$ $Q E \cdot g^{-1}$. These biscuits had higher concentration of crude fibre in comparison with the control group and the highest concentration (0.64\%) was found in biscuits with addition of $3 \%$ green tea powder. The amino acid composition in samples, including in the control sample was balanced, with slightly higher concentration of threonine, serine, and methionine in enriched samples, but this parameter was not statistically significant. Biscuits enriched with green and black tea had higher sensory scores for taste, smell and aftertaste.
\end{abstract}

Key words: biscuits, antioxidant activity, polyphenols, crude fibre, amino acids.

\section{INTRODUCTION}

Due to consumer demand for healthier foods, the food industry is directing new product development towards the area of functional foods and ingredients (Pasqualone et al., 2014). Natural extracts of plant origin can provide bioactive properties and bring additional value to the final products (Galeja et al., 2017). Natural extracts from aromatic plants, spices, and fruit powder have been incorporated in some bakery products as sources of antioxidant. The advantage of new functional ingredients is that food manufacturers can add extra value to products that the consumer is already fa- miliar with. The main factors that have to be considered are the variations affecting the processing conditions, sensory properties and nutritional value of final product. Biscuits could represent a potential product for the addition of functional ingredients, but their nutritional profile has to be improved in view of formulating functional products (Taylor et al., 2008; Sultan et al., 2011; Pasqualone et al., 2014). Natural products used as food supplements are recently gaining more and more attention and tea particularly is an area of interest. In fact, tea leaves (Camellia sinensis L.) are the source of the world's most popular beverage, which is rich in polyphenols, flavonoids such as flavanols (catechins, 
procyanidins), flavonols (rutin, quercetin, kaempferol) and phenolic acids (gallic, caffeic). Polyphenolic compounds in tea leaves make up to $30 \%$ of green tea, but only $10 \%$ of black tea (Gramza-Michalowska et al., 2016). Tea antioxidants have drawn increased attention in recent years because of their potential health benefits, not only as antioxidant agents but also as antiarteriosclerotic, anti-carcinogenic, and antimicrobial agents. They may contribute the risk reduction of chronic diseases and cancer, promoting oral health and prolonging the shelf life of food products without damaging their organoleptic or nutritional qualities (Wang and Zhou, 2004; Sharma and Zhou, 2011). The use of green tea extracts in foods as bread, cereals, cakes, biscuits, dairy products, noodles, instant noodles, confectionery, and ice cream attract consumer attention due to healthy properties of the products (Sharma and Zhou, 2011).

The aim of the present study was to evaluate biological and sensory characteristics of biscuits enriched with Camellia sinensis L. powder.

\section{MATERIALS AND METHODS}

Material. Flour (wheat, T-00 extra), pure sugar beet sugar, salt, butter, sodium bicarbonate, vanilla, green tea (Matcha, Japan) and black tea (Earl Grey, Japan) were obtained from the local market in Slovakia. All chemicals were analytical grade and were purchased from Reachem (Slovakia) and Sigma Aldrich (USA).

Methods. Biscuit preparation. The sweet biscuits were prepared by using the AACC method (Anonymous, 1984) with slight modification. The ingredients included wheat flour $(100 \mathrm{~g})$, butter $(30 \mathrm{~g})$, sugar $(10 \mathrm{~g})$, salt $(1 \mathrm{~g})$, sodium bicarbonate $(1 \mathrm{~g})$, vanilla $(0.025 \mathrm{~g})$, and the required amount of water. Preparation of biscuits was carried out using wheat flour samples enriched with $1 \%$ and $3 \%$ of green tea (Matcha powder) and 1\% and 3\% of black tea (Earl Grey). Each type of biscuit was prepared separately. Shortening and creaming technique were used. The biscuits were baked at $160{ }^{\circ} \mathrm{C}$ for $20 \mathrm{~min}$ (oven Miwe condo, Germany). After cooling for $30 \mathrm{~min}$, the cookies were packed and evaluated for biological and sensory characteristics.

Analytical methods. Crude fibre concentration was evaluated by an Ancom ${ }^{200}$ Fiber Analyzer (USA) according to the manufacturer method. Total ash concentration was determined after complete burning of the sample in an oven (Anonymous, 2000). Amino acids were determined by ionexchange chromatography with a strong cation ionexchanger and sodium-citrate elution buffers system followed by post-column derivatisation with ninhydrin and spectrophotometric detection, according to standard protocol of the manufacturer of the amino acid analyser (Ingos, Czech Republic). For calibration of the amino acid analyser, amino acid standard solutions were used. Tryptophan was not determined as it was destroyed during acid hydrolysis. Asparagine and glutamine turned to aspartic acid and glutamic acid that made them detectable in these forms.
Extraction for determination of total phenol, total flavonoid concentration and antioxidant activity. The biscuits after homogenisation in a mortar were used for preparation of ethanolic extract and an amount of $0.5 \mathrm{~g}$ of each sample was extracted with $40 \mathrm{ml}$ of $80 \%$ ethanol for 24 hours. After centrifugation at $4000 \mathrm{~g}$ (Rotofix 32 A, Hettich, Germany) for $10 \mathrm{~min}$, total phenolic and total flavonoid concentration and antioxidant activity with DPPH and phosphomolybdenum methods were measured in the supernatant.

Free radical scavenging activity. Free radical scavenging activity of samples was measured with 2,2-diphenyl-1picrylhydrazyl (DPPH) radical (Yen and Chen, 1995). The sample $(1 \mathrm{ml})$ was mixed with $4 \mathrm{ml}$ DPPH solution $(0.025 \mathrm{~g}$ DPPH in $100 \mathrm{ml}$ methanol). Absorbance of the reaction mixture was determined with a spectrophotometer Jenway (6405 UV/Vis, England) at $515 \mathrm{~nm}$. Trolox (6-hydroxy2,5,7,8-tetramethylchroman-2-carboxylic acid) (10-100 $\mathrm{mg} \cdot \mathrm{l}^{-1} ; \mathrm{R}^{2}=0.989$ ) was used as the standard and the results were expressed in $\mathrm{mg} / \mathrm{g}$ Trolox equivalents.

Molybdenum reducing antioxidant power. Molybdenum reducing antioxidant power of samples was determined by the method of Prieto et al. (1999) with slight modifications. A mixture composed of a sample $(1 \mathrm{ml})$, monopotassium phosphate $(2.8 \mathrm{ml}, 0.1 \mathrm{M})$, sulfuric acid $(6 \mathrm{ml}, 1 \mathrm{M})$, ammonium heptamolybdate $(0.4 \mathrm{ml}, 0.1 \mathrm{M})$ and distilled water $(0.8 \mathrm{ml})$ was incubated at $90{ }^{\circ} \mathrm{C}$ for $120 \mathrm{~min}$, then rapidly cooled and the absorbance at $700 \mathrm{~nm}$ was measured with a spectrophotometer Jenway (6405 UV/Vis, England). Trolox $\left(10-1000 \mathrm{mg} \cdot \mathrm{l}^{-1} ; R^{2}=0.998\right)$ was used as the standard and the results were expressed in $\mathrm{mg} / \mathrm{g}$ Trolox equivalents.

Total polyphenol concentration. Total polyphenol concentration of samples was measured by the method of Singleton and Rossi, (1965) with Folin-Ciocalteu reagent. A quantity of $0.2 \mathrm{ml}$ of each sample was mixed with $0.2 \mathrm{ml}$ Folin-Ciocalteu reagent, $2 \mathrm{ml} 20 \%$ (w/v) sodium carbonate and $8.8 \mathrm{ml}$ distilled water. After $30 \mathrm{~min}$ in darkness, the absorbance at $700 \mathrm{~nm}$ was measured with a spectrophotometer Jenway (6405 UV/Vis, England). Gallic acid (25-300 $\left.\mathrm{mg} \cdot \mathrm{l}^{-1} ; R^{2}=0.998\right)$ was used as the standard and the results were expressed in $\mathrm{mg} \cdot \mathrm{g}^{-1}$ gallic acid equivalents.

Total flavonoid concentration. Total flavonoid concentration was determined by the modified method of QuettierDeleu et al. (2000). An amount of $2 \mathrm{ml}$ of sample was mixed with $0.4 \mathrm{ml}$ of $5 \%(\mathrm{w} / \mathrm{v})$ ethanolic solution of aluminum chloride. After $30 \mathrm{~min}$ in darkness, the absorbance at $415 \mathrm{~nm}$ was measured with a spectrophotometer Jenway (6405 UV/Vis, England). Quercetin (1-400 mg. $\mathrm{l}^{-1} ; R^{2}=$ 0.9977 ) was used as the standard and the results were expressed in $\mathrm{mg} / \mathrm{g}$ quercetin equivalents.

Sensory characteristic. The organoleptic properties of prepared biscuits were determined by a taste panel consisting of 10 evaluators (experts). The panelists were asked to evaluate the flavour of the product, tea flavour (intensity), tea flavour (presence), taste, tea taste (presence), tea taste 
CRUDE FIBRE AND TOTAL ASH CONCENTRATION IN BISCUITS

\begin{tabular}{l|c|c|c|c}
\hline \multicolumn{1}{c|}{ Parameter } & B1\% GT & B3\% GT & B1\% BT & B3\% BT \\
\hline Crude fibre content, \% & $0.61 \pm 0.02$ & $0.64 \pm 0.01$ & $0.57 \pm 0.01$ & $0.59 \pm 0.02$ \\
Ash content, \% & $2.13 \pm 0.03$ & $2.21 \pm 0.12$ & $2.27 \pm 0.01$ & $0.56 \pm 0.01$ \\
\hline
\end{tabular}

B1\% GT, biscuits with $1 \%$ green tea powder; B3\% GT, biscuits with $1 \%$ green tea powder; B1\% BT, biscuits with $1 \%$ black tea powder; B3\% BT, biscuits with $3 \%$ black tea powder; mean \pm standard deviation

(intensity), aftertaste, character of tea taste, and overall acceptability. All parameters were compared with a control sample (sample without tea addition). The ratings were based on a 9-point hedonic scale, ranging from 9 (like extremely) to 1 (dislike extremely) for each characteristic.

Statistical analysis. All experiments were carried out in triplicate and the results reported are the results of those replicate determinations with standard deviation. Correlation coefficients were calculated by CORR analysis ( $p \leq$ 0.005) (Anonymous, 2009).

\section{RESULTS}

Crude fibre, total ash and amino acid concentration. Analyses of crude fiber, total ash and amino acid concentration are shown in Tables 1 and 2. Biscuits with no tea added (control sample) contained lower levels of ash and crude fibre. In terms of the crude fibre concentration, the biscuits can be ordered as follows: biscuits with $3 \%$ green tea $>$ biscuits with $1 \%$ green tea $>$ biscuits with $3 \%$ black tea $>$ biscuits with $1 \%$ black tea $>$ control sample. In terms of the total ash concentration, the biscuits can be ordered as follows: biscuits with $3 \%$ black tea $>$ biscuits with $1 \%$ black tea $>$ biscuits with $1 \%$ and $3 \%$ green tea $>$ control sample. Amino acid composition was similar in all prepared biscuits, however, taking into account that the addition of black tea resulted in increased concentration of aspartic acid, glutamic acid and proline in comparison with control sample, but this increase of concentration was not statistically significant.

Antioxidant activity, total polyphenol and flavonoid concentration. The antioxidative activity of biscuits enriched with tea leaves powder is presented in Table 3 . The results showed that the addition of tea powder in dough resulted in significant increase of antioxidative potential in all the samples tested. The free radical scavenging activity assay dem-
Table 2

AMINO ACID CONCENTRATION IN PREPARED BISCUITS

\begin{tabular}{l|c|c|c|c|c}
\hline $\begin{array}{c}\text { Amino } \\
\text { acid, }\end{array}$ & B1\% GT & B3\% GT & B1\% BT & B3\% BT & Control \\
\hline Asp & $0.24 \pm 0.00$ & $0.27 \pm 0.00$ & $0.26 \pm 0.02$ & $0.29 \pm 0.00$ & $0.27 \pm 0.00$ \\
Thr & $0.17 \pm 0.00$ & $0.19 \pm 0.00$ & $0.18 \pm 0.01$ & $0.18 \pm 0.00$ & $0.19 \pm 0.00$ \\
Ser & $0.31 \pm 0.00$ & $0.34 \pm 0.01$ & $0.33 \pm 0.01$ & $0.34 \pm 0.01$ & $0.34 \pm 0.00$ \\
Glu & $2.42 \pm 0.03$ & $2.86 \pm 0.04$ & $2.75 \pm 0.11$ & $2.85 \pm 0.03$ & $2.80 \pm 0.01$ \\
Pro & $0.79 \pm 0.07$ & $0.87 \pm 0.01$ & $0.85 \pm 0.03$ & $0.91 \pm 0.00$ & $0.86 \pm 0.01$ \\
Gly & $0.22 \pm 0.00$ & $0.26 \pm 0.00$ & $0.25 \pm 0.01$ & $0.25 \pm 0.00$ & $0.25 \pm 0.00$ \\
Ala & $0.19 \pm 0.00$ & $0.22 \pm 0.00$ & $0.21 \pm 0.01$ & $0.21 \pm 0.00$ & $0.21 \pm 0.00$ \\
Val & $0.27 \pm 0.00$ & $0.31 \pm 0.00$ & $0.31 \pm 0.01$ & $0.31 \pm 0.00$ & $0.31 \pm 0.00$ \\
Ile & $0.25 \pm 0.01$ & $0.29 \pm 0.00$ & $0.28 \pm 0.01$ & $0.28 \pm 0.00$ & $0.28 \pm 0.01$ \\
Leu & $0.45 \pm 0.01$ & $0.52 \pm 0.00$ & $0.51 \pm 0.02$ & $0.51 \pm 0.00$ & $0.51 \pm 0.01$ \\
Tyr & $0.24 \pm 0.01$ & $0.22 \pm 0.00$ & $0.22 \pm 0.01$ & $0.22 \pm 0.00$ & $0.23 \pm 0.01$ \\
Phe & $0.33 \pm 0.01$ & $0.38 \pm 0.00$ & $0.36 \pm 0.02$ & $0.37 \pm 0.00$ & $0.37 \pm 0.01$ \\
His & $0.18 \pm 0.00$ & $0.23 \pm 0.00$ & $0.21 \pm 0.01$ & $0.22 \pm 0.00$ & $0.23 \pm 0.00$ \\
Lys & $0.08 \pm 0.00$ & $0.11 \pm 0.00$ & $0.11 \pm 0.00$ & $0.11 \pm 0.00$ & $0.11 \pm 0.00$ \\
Arg & $0.23 \pm 0.00$ & $0.25 \pm 0.00$ & $0.25 \pm 0.01$ & $0.24 \pm 0.01$ & $0.25 \pm 001$ \\
Cys & $0.13 \pm 0.02$ & $0.14 \pm 0.00$ & $0.15 \pm 0.01$ & $0.14 \pm 0.00$ & $0.15 \pm 0.01$ \\
Met & $0.12 \pm 0.01$ & $0.12 \pm 0.01$ & $0.11 \pm 0.00$ & $0.11 \pm 0.00$ & $0.11 \pm 0.01$
\end{tabular}

B1\% GT, biscuits with $1 \%$ green tea powder; B3\% GT, biscuits with $1 \%$ green tea powder; B1\% BT, biscuits with $1 \%$ black tea powder; B3\% BT, biscuits with $3 \%$ black tea powder; Asp, aspartic acid; Thr, threonine; Ser, serine; Glu, glutamic acid; Pro, proline; Gly, glycine; Ala, alanine; Val, valine; Ile, isoleucine; Leu, leucine; Tyr, tyrosine; Phe, phenylalanine; His, histidine; Lys, lysine; Arg, arginine; Cys, cysteine; Met, methionine; mean \pm deviation

onstrated that activity increased with addition of tea from 1.04 to $2.25 \mathrm{mg}$ TEAC. ${ }^{-1}$; and molybdenum reducing antioxidant power from 26.93 to $32.65 \mathrm{mg} \mathrm{TEAC} \cdot \mathrm{g}^{-1}$. The fortification of biscuits with tea leaves powder led to statistically significant enrichment in total polyphenol and flavonoid concentration (Table 3) in comparison to that of the control sample. Pearson correlation coefficients between

Table 3

ANTIOXIDANT ACTIVITY, TOTAL POLYPHENOL AND FLAVONOID CONCENTRATION IN PREPARED BISCUITS

\begin{tabular}{lcc|c|cc}
\hline \multicolumn{1}{c|}{ Parameter } & B1\% GT & B3\% GT & B1\% BT & B3\% BT & Control \\
\hline DPPH [mg TEAC/g] & $1.28 \pm 0.05$ & $1.48 \pm 0.03$ & $1.53 \pm 0.01$ & $2.25 \pm 0.12$ \\
MRAP [mg TEAC/g] & $28.13 \pm 0.24$ & $28.46 \pm 0.12$ & $30.00 \pm 1.02$ & $32.65 \pm 1.42$ \\
TPC [mg GAE/g] & $0.37 \pm 0.09$ & $0.27 \pm 0.03$ & $0.40 \pm 0.02$ & $1.17 \pm 0.02$ \\
TFC [mg QE/g] & $0.02 \pm 0.00$ & $0.03 \pm 0.00$ & $0.09 \pm 0.01$ & $0.14 \pm 0.00$ & n.d
\end{tabular}

B1\% GT, biscuits with $1 \%$ green tea powder; B3\% GT, biscuits with 3\% green tea powder; B1\% BT, biscuits with $1 \%$ black tea powder; B3\% BT, biscuits with $3 \%$ black tea powder; mean \pm standard deviation; DPPH, 2,2-diphenyl-1-picrylhydrazyl; MRAP, molybdenic reducing antioxidant power; TPC, total polyphenol content; TFC, total flavonoid content; TEAC, Trolox equivalent antioxidant capacity; GAE, gallic acid equivalent; QE, quercetin equivalent; n.d., not detected 


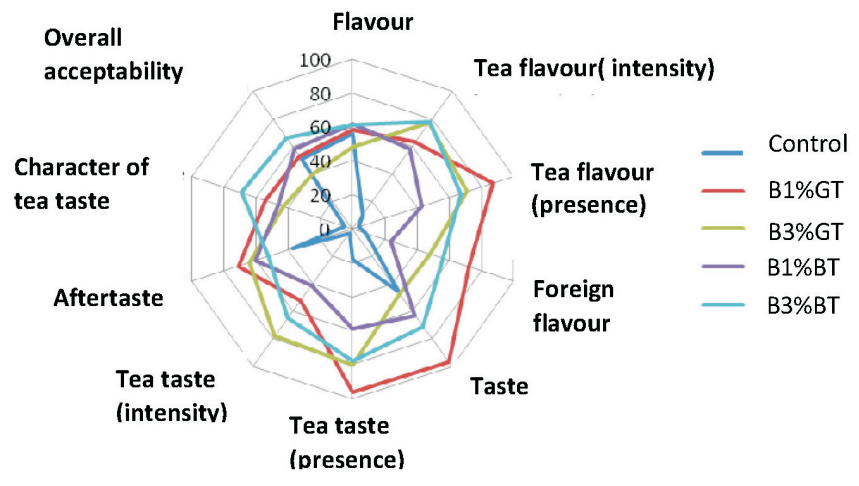

Fig. 1. Sensory profiles of prepared biscuits (sum of all evaluations).

B1\% GT, biscuits with $1 \%$ green tea powder; B3\% GT, biscuits with $3 \%$ green tea powder; B1\% BT, biscuits with $1 \%$ black tea powder; B3\% BT, biscuits with $3 \%$ black tea powder; mean \pm standard deviation

total polyphenol concentration and reducing power of biscuits $(r=0.977)$ and between free radical scavenging activity and total polyphenol concentration of biscuits $(r=$ 0.973 ) were statistically significant.

Sensory characteristic. The results of taste (Fig. 1), flavour, and overall acceptability of prepared biscuits showed no strong differences in sensory evaluations. Biscuits varied in terms of their aftertaste. Some evaluators felt a 'grass taste' after consumption of biscuits with 3\% green powder. After consumption of biscuits with $3 \%$ black tea, some evaluators felt a pleasant honey and chamomile aftertaste. Generally all prepared biscuits were evaluated as harmonic, pleasant with the best evaluation for the sample with $1 \%$ green tea powder and $3 \%$ black tea powder.

\section{DISCUSSION}

The present study showed that addition of tea leaves powder resulted in slightly increased concentration of crude fibre. Fibre exerts significant influence on human health and well-being and exhibits effect in prevention of arteriosclerosis, reducing risk of coronary heart disease, protecting against colon cancer, and lowering glucose, cholesterol and triglycerides concentrations in blood (Chawl and Patil, 2010). Gramza-Michalowska et al. (2016) determined dietary fibre fractions in cookies prepared with green and yellow tea leaves, and confirmed that tea leave addition increased the neutral dietary fibre concentration (13.54$14.77 \%$ ) in comparison to the control (10.33\%).

Biscuits enriched with tea leaves powder contained higher level of total ash in comparison with control samples. Similar results were reported by Lu et al. (2010) and GramzaMichalovska et al. (2016), where sponge cake and cookies were fortified with tea.

The results revealed that biscuits enriched with $3 \%$ of green tea shared slightly increased amounts of isoleucine, leucine and phenylalanine, while the biscuits enriched with $3 \%$ of black tea revealed the increased concentration of three amino acids (aspartic acid, glutamic acid and proline). Tea is a very specific product and contains theanine, $\gamma$-glutamyl- ethylamide or 5-N-ethyl glutamine - non-protein amino acid, which is the main free amino acid in teas, representing as much as $50 \%$ of the total amino acid content in black tea and $1-2 \%$ of dry weight of green tea. It is involved in many biological effects such as promoting relaxation, inhibiting caffeine's negative effects and reducing blood pressure (Hara et al., 1995; Wang et al., 2010). In our study, this amino acid was not detected, but is very likely that enriched biscuits with tea powder also contained this specific amino acid.

Addition of tea powder increased the antioxidant activity of biscuits in comparison with control samples. Also GramzaMichalovska et al. (2010) found that cookies enriched with green and yellow leaves had significant higher antioxidant activity by DPPH, oxygen radical absorbance capacity ORAC), and 2,2'-azino-bis(3-ethylbenzothiazoline-6sulphonic acid (ABTS) method. The authors concluded that tea leaves can cause significant increase of total polyphenol concentration. Tea is one of the richest sources of antioxidants. The major antioxidants in tea are catechins, theaflavins, thearubigins, oxyaromatic acids, flavonols, (kaempferol, myricetin, quercetin), flavones such as apigenin and derivatives of gallic acid, such as tannins, etc. Green tea is known as an outstanding source of antioxidants, which is characterised by the presence of large amount of flavan-3-ols known as catechins (Yashin et al., 2011). Sharma and Zhou, (2011) incorporated green tea extracts into biscuits and observed stability of catechins in the biscuits making process. The obtained results showed that green tea catechins were relatively stable in dough and their stability decreased as the baking progressed and increased as the concentration of green tea extract was increased in the biscuit dough. The stability of (-)-EGCG increased alongside with $\mathrm{pH}$ of the dough and decreased when $\mathrm{pH}$ was neutral or slightly acidic.

Biscuit is a complex system containing wheat protein, starch, water, fat, and sugar and is a combination of aqueous and lipid phases. In comparison with the bread, the biscuit matrix has a far higher proportion of the lipid phase and sugar, which makes it unique in itself. Loss of catechins could be attributable to the combined effect of alkaline $\mathrm{pH}$, interactions of the catechins with certain components of the dough, the epimerisation or oxidation of catechins during baking and the degradation of catechins during the various biscuit making stages, including mixing and baking. Higher concentration of total polyphenol and (-)-EGCG was found than in other studies, which was due to high stability of flavonols and phenolic acid during the baking. Sharma and Zhou (2011) used a baking temperature of $160{ }^{\circ} \mathrm{C}$ for 10 min, but in our study the same temperature was combined with a longer baking process. Therefore, we can conclude that the samples before the treatment contained higher concentration of biologically active compounds.

The addition of new plant components into dairy and other products might be a challenge for a producer in terms of marketing success. The addition of tea leave powder has been known for many years in Japan, where many retailed products contain powdered green tea (Matcha) (Gramza- 
Michalovska et al. 2016). This initiated motivation to create a simple product with the direct addition of various tea leaves. Consumers evaluated the sensory characteristics of the product as good with the best overall acceptability of products with $1 \%$ green tea and $3 \%$ of black tea powder addition (Fig. 1). Sensory characteristics (taste, aroma, colour, crispness, and overall consumer acceptance) of cookies with yellow and green tea in study of Gramza-Michalovska et al. (2016) were determined with a ten-point hedonic scale and did not revealed differences in sensory evaluations of freshly baked cookies regarding the taste, aroma and crispness tests. However, overall acceptance of cookies was variable. Evaluator remarks were focused on the grassy aftertaste in cookies enriched with tea as in other studies.

\section{CONCLUSION}

Our results showed that green and black tea leave powder can be significant tools in improvement of the nutritional value and antioxidant activity of biscuits. The addition of tea leave powder resulted in a significant increase of the crude fibre and ash concentration, but increase of amino acids concentration was not significantly. Biscuits enriched with tea leaves had significantly higher antioxidant potential, which was associated with its polyphenol and flavonoid concentration. We can conclude that the tea leaves can be widely used as a source of polyphenols, crude fibre, ash and therefore they could be beneficial for human health.

\section{ACKNOWLEDGEMENTS}

This work was co-funded by the European Community project No. 26220220180: Building the Research Centre "AgroBioTech" and VEGA 1/0411/17.

\section{REFERENCES}

Anonymous (1984). Approved Methods of Analysis. St. Paul, Minnesota: The American Association of Cereal Chemists. 556 pp.

Anonymous (2000). Official Methods of Analysis: Official Method for Ash. Washington DC: Association of Official Analytical Chemists: Method No. 936.03. $960 \mathrm{pp}$.
Anonymous (2009). Users Guide Version 9. 2. SAS/STAT (r) SAS Institute Inc. Cary, NC, USA

Chawla, R., Patil, G. R. (2010). Soluble dietary fiber. Com. Rev. Food Scien. Food Saf., 9, 178-196.

Gramza-Michlowska, A., Kobus-Cisowska, J., Kmiecik, D., Korczak, J., Helak, B., Dziedzic, K., Górecka, D. (2011). Antioxidative potential, nutritional value and sensory profiles of confectionery fortified with green and yellow tea leaves (Camellia sinensis). Food Chem., 211, 448-454.

Hara, Y., Luo, S., Wikramasinghe, R. L., Yamanishi, T. (1995). Special issue on tea. Food Rev. Inter., 11, 371-545.

Lu, T. M., Lee, C. C., Mau, J. L. Lin, S. D. (2010). Quality and antioxidant property of green tea sponge cake. Food Chem., 119, 1090-1095.

Pasqualone, A., Bianco, A. M., Paradiso, V. M., Summo, C., Gambacorta, G., Capanio, F. (2014). Physico-chemical, sensory and volatile profiles of biscuits enriched with grape marc extract. Food Res. Intern., 65, 385-393.

Prieto, P., Pinera, M., Aguilar, M. (1999). Spectrophotometric quantitation of antioxidant capacity through the formation of a phosphomolybdenum complex: Specific application to the determination of vitamin E. Anal. Biochem. 269, 334-337.

Quettier-Deleu, Ch., Gressier, B., Vesseur, J., Dine, E., Brunet, C., Luyckx, M., Cazin, M., Cazin, J. C., Bailleul, F. (2000). Phenolic compounds and antioxidant activities of buckwheat (Fagopyrum esculentum Moench) hulls and flour. J. Ethnopharm., 1-2, 35-42.

Sharma, A., Zhou, W. (2011). Stability of green tea catechins during the biscuit making process. Food Chem., 126, 568-573.

Singleton, V. L., Rossi, J. A. (1965). Colorimetry of total phenolics with phosphomolybdic-phosphotungstic acid reagents. Amer. J. Enol. Agric. 6, $144-158$.

Sultan, M. T., Butt, M. S., Pasha, I., Qayyum, M. M. N., Saeed, F., Ahmad, W. (2011). Preparation and evaluation of dietetic cookies for vulnerable segments using black cumin fixed oil. Pakistan J. Nutr., 10, 451-456.

Taylor, T. P. Fasina, O., Bell, L. (2008). Physical properties and consumer liking of cookies prepared by replacing sucrose with tagatose. J. Food Science, 73, 145-151.

Wang, L., Xu, R., Hu, B., Li, W., Sun, Y., Tu, Y., Zeng, X. (2010). Analysis of free amino acids in Chinese teas and flavour of tea plant by high liquid chromatography combined with solid-phase extraction. Food Chem., 123, 1259-1266.

Wang, R., Zhow, W. (2004). Stability of tea catechins in the bread making process. J. Agri. Food Chem., 52, 8224-8229.

Yashin, A., Yashin Y., Nemzer, B. (2011). Determination of antioxidant activity in tea extracts and their total antioxidant content. Amer. J. Biom. Scien., 13, 322-335.

Yen, G. C., Chen, H. Y. (1995). Antioxidant activity of various tea extracts in relation to their antimutagenicity. J. Agri.Food Chem., 43, 27-32.

Received 5 October 2016

Accepted in the final form 17 January 2018

\section{BIOLOG̣ISKO UN SENSORO İPAŠĪBU NOTEIKŠANA CEPUMOS AR ZAḶĀS UN MELNĀS TĒJAS (CAMELLIA SINENSIS L.) PULVERA PIEDEVU}

Darba mērkis bija noskaidrot cepumu ar zaḷās un melnās tējas pulveru piedevu, kuru pievienošanas daudzums ir 1\% un 3\%, bioloǵisko vērtību un sensoro īpašǐbu intensitāti (garša, smarža, pēcgarša). Kā kontroles paraugs tika izmantoti cepumi bez tējas pulveru piedevas. Kopējo fenolu un flavonoīdu saturs, kā arī antioksidantu aktivitāte tika noteikta ar spektrofotometru, bet animoskābju sastāvs, — pielietojot aminoskābju analizatoru AAA 400. Sensoro īpašību intensitātes novērtēšana veikta, savā starpā salīizinot cepumu paraugus ar tēju pulvera piedevām un kontroles paraugu. Salīdzinot ar kontroles paraugu, cepumu paraugos ar tējas pulveru piedevu noteikts augstāks fenolu un flavonoīdu saturs, kā arī lielāka antioksidantu aktivitāte, izmantojot DPPH un fosfomolibdēna metodi. Visaugstāko antioksidantu aktivitāti uzrādīja cepumu paraugi ar 3\% melnās tējas pulvera piedevu un, nosakot ar DPPH un fosfomolibdēnu metodēm, bija attiecīgi 2,30 un 33,45 mg TEAC.g ${ }^{-1}$. Savukārt kopējais fenolu saturs bija $1,16 \mathrm{mg} \mathrm{GSE} \cdot \mathrm{g}^{-1}$, bet kopējais flavonoīdu saturs $0,13 \mathrm{mg} \mathrm{KE} \cdot \mathrm{g}^{-1}$. Salīdzinot ar kontroles paraugu, cepumu paraugos ar tējas pulvera piedevu tika noteikts augstāks škikiedrvielu saturs, respektīvi, augstāks škiedrvielu saturs $(0,65 \%)$ tika konstatēts cepumos ar 3\% zaḷās tējas piedevu. Eksperimentu gaitā tika noskaidrots, ka visos paraugos, ir sabalansēts aminoskābju sastāvs ar nedaudz augstāku treonīna, serīna un metionīna saturu cepumu paraugos ar tējas pulvera piedevām. Cepumos ar zaḷās un melnās tējas pulveru piedevu noteikta augstāka sensoro īpašỉbu — garšas, smaržas un pēcgaršas — intensitāte. 